\title{
NXPE Family Member 1
}

National Cancer Institute

\section{Source}

National Cancer Institute. NXPE Family Member 1. NCI Thesaurus. Code C131202.

NXPE family member 1 (547 aa, $\sim 63 \mathrm{kDa}$ ) is encoded by the human NXPE1 gene. This protein may play a role in the metabolism of lipids. 